\title{
SISTEM PENGOLAHAN LIMBAH CAIR \\ DI RSUD SYARIFAH AMBAMI RATO EBU BANGKALAN
}

Erna Wahyuningsih ${ }^{1}$, Iva Rustanti Eri Wardoyo ${ }^{2}$, Pratiwi Hermiyanti ${ }^{3}$

${ }^{1}$ RSUD Syarifah Ambami Rato Ebu Bangkalan

2,3 Jurusan Kesehatan Lingkungan Poltekkes Kemenkes Surabaya

Email : pratiwi@poltekkesdepkes-sby.ac.id

\begin{abstract}
ABSTRAK
Limbah cair adalah semua air buangan termasuk tinja yang dikeluarkan dari kegiatan rumah sakit yang kemungkinan mengandung mikroorganisme, bahan kima beracun dan radioaktif berbahaya bagi kesehatan. Pengolahan limbah cair rumah sakit harus memenuhi syarat baku mutu. Penelitian ini bertujuan untuk mengetahui sistem pengolahan limbah cair di RSUD Syarifah Ambami Rato Ebu Bangkalan yang meliputi Sumber-sumber limbah cair, Unit -unit Pengolahan, Proses Pengolahan, dan Kualitas Parameter.

Penelitian ini bersifat deskriptif yaitu untuk mengetahui gambaran sistem pengolahan limbah cair di RSUD Syarifah Ambami Rato Ebu Bangkalan. Obyek penelitian ini adalah pemeriksaan terhadap kualitas limbah cair di IPAL RSUD Syarifah Ambami Rato Ebu Bangkalan dengan pengambilan sampel satu bulan sekali.

Dari hasil pengukuran parameter limbah cair yang diujikan ke laboratorium DLH Provensi Jawa Timur diketahui hasil uji lab NH3 dan E-coli melebihi baku mutu dan tidak sesuai Pergub Jatim No. 72. Tahun 2017. NH3 $=1.05 \mathrm{Mg} / \mathrm{l}$, Baku Mutu $(0,1 \mathrm{Mg} / \mathrm{l})$. E-coli $=$ $35.000 / 100 \mathrm{ml}$ Baku Mutu (10.000/100ml). Penyebab NH3 melebihi baku mutu disebabkan karena pada proses pengolahan di unit ruang aerob tangki 3 mesin blower mati. Sedangkan penyebab e-Coli tinggi adalah proses klorinasi yang kurang tepat.

Kesimpulan dari penelitian pemeriksaan kualitas parameter $\mathrm{NH} 3$ dan e-Coli yang berasal dari Outlet IPAL tidak memenuhi syarat baku mutu. Disarankan bagi manajemen RSUD Syarifah Ambami Rato Ebu Bangkalan untuk mengganti mesin blower yang baru dan penambahan klorin harus disesuaikan dengan takaran dosis yang tepat.
\end{abstract}

Kata Kunci : Rumah Sakit, Sistem Pengolahan Limbah Cair

\section{PENDAHULUAN}

Rumah sakit merupakan institusi pelayanan kesehatan dengan inti kegiatan pelayanan preventif, kuratif, rehabilitatif dan promotif. Kegiatan tersebut akan menimbulkan dampak positif dan negatif. Dampak positif adalah meningkatnya derajat kesehatan masyarakat, sedangkan dampak negatifnya antara lain adalah sampah dan limbah medis maupun non medis yang dapat menimbulkan penyakit dan pencemaran yang perlu perhatian khusus. Oleh karenanya perlu upaya penyehatan lingkungan rumah sakit yang bertujuan untuk melindungi masyarakat dan karyawan akan bahaya pencemaran lingkungan yang bersumber dari sampah maupun limbah rumah sakit. Sampah atau limbah rumah sakit dapat mengandung bahaya karena dapat bersifat racun, infeksius dan juga radioaktif (Andi, 2011)

Limbah rumah sakit dapat mencemari lingkungan penduduk di sekitar rumah sakit dan dapat menimbulkan masalah kesehatan. Hal ini dikarenakan limbah rumah sakit mengandung berbagai jasad renik penyebab penyakit pada manusia termasuk demam typoid, kholera, disentri dan hepatitis sehingga limbah tersebut harus diolah sesuai dengan pengelolaan limbah medis sebelum dibuang ke lingkungan (BAPEDAL, 2010).

Disamping peranan rumah sakit sebagai pelayanan kesehatan, tentu rumah sakit menghasilkan limbah cair. Limbah cair rumah rakit mulai disadari sebagai bahan buangan yang dapat menimbulkan gangguan kesehatan baik 
pada manusia maupun lingkungan sekitar rumah sakit karena bahan-bahan beracun yang terkandung di dalamnya dapat menimbulkan berbagai penyakit.

IPAL merupakan suatu sarana atau tempat penampungan dan pengolahan limbah cair sebelum dibuang ke sekitar lingkungan rumah sakit. Dewasa ini masih ada beberapa rumah sakit yang belum memiliki sarana Instalasi Pengolahan Limbah cair (IPAL). Untuk itu dibutuhkan sosialisasi kebijakan pedoman dan standar pembangunan sarana dan prasarana rumah sakit baik di Kota maupun di daerah terpencil, perbatasan kepulauan serta pemekaran daerah. Limbah cair yang dibuang dari rumah sakit dalam kondisi kurang baik, mengandung bahan berbahaya, infeksius dan bersifat radioaktif yang membahayakan kehidupan. Oleh karena itu pembangunan rumah sakit harus disertai dengan pengawasan, pemantauan, dan perhatian terhadap limbah rumah sakit yang dihasilkan. Kondisi ini mengharuskan setiap pengelola industri khususnya industri jasa rumah sakit harus memperhatikan cara-cara pengolahan dan pembuangan limbah cair agar tidak menimbulkan permasalahan bagi lingkungan maupun bagi kesehatan masyarakat disekitar rumah sakit.

Rumah Sakit Umum Syarifah Ambami Rato Ebu Bangkalan adalah Rumah Sakit tipe B Pendidikan, dan satusatunya rumah sakit pemerintah yang ada di Kabupaten Bangkalan. Selain peranannya sebagai pelayanan kesehatan, Rumah Sakit Umum Syarifah Ambami Rato Ebu Bangkalan menghasilkan limbah cair. Namun menurut hasil pemeriksaan laboratorium terhadap sampel limbah cair rumah sakit yang dikirim ke Dinas Lingkungan Hidup Provinsi Jawa Timur dalam kurun waktu pada bulan Pebruari 2019 s/d Nopember 2019 menunjukan hasil pada outlet limbah cair dimana kadar NH3 dan E Coli melebihi nilai ambang batas dan tidak memenuhi baku mutu limbah cair bagi rumah sakit berdasarkan Peraturan Gubernur Jaawa
Timur nomor 72 tahun 2013. Jika pengolahan limbah cair Rumah Sakit Syarifah Ambami Rato Ebu Bangkalan tidak diolah dengan baik akan dapat menjadi sumber dan menimbulkan berbagai penyakit. Tujuan penelitian ini adalah untuk mengetahui sistem pengolahan limbah cair dan mengetahui kualitas parameter limbah cair di Rumah Sakit Syamrabu Bangkalan

\section{METODOLOGI PENELITIAN}

Metode penelitian ini adalah metode deskriptif menggambarkan kondisi dan melihat kinerja Instalasi Pengolah Limbah (IPAL). Penelitian dilakukan di IPAL RSUD Syarifah Ambami Rato Ebu (Syamrabu) Bangkalan. Obyek Penelitian ini adalah pemeriksaan terhadap kualitas limbah cair

Idi IPAL RSUD Syamrabu Bangkalan. Pengambilan sampel dilakukan sebanyak 1 kali setiap bulan terhitung bulan Pebruari 2019 sampai dengan Nopember 2019 dengan volume pengambilan sampel limbah cair 3 liter.

\section{HASIL DAN PEMBAHASAN}

Adapun yang menjadi sumber sumber limbah cair yang ada di rumah sakit Syamrabu Bangkalan adalah: Ruang Operasi,Ruang Rawat Inap, Dapur, Ruang Rawat Jalan, ICU, IGD dan Loundry. Semua limbah cair yang dihasilkan dari semua ruangan dialirkan ke IPAL. Untuk limbah cair yang berasal dari Dapur/Gizi ditampug pada bak khusus/ bak penangkap lemak (Grease trap) dan proses pengolahanya dilakukan secara fisik agar lemak dapat ditangkap dan tidak bercampur dengan air.

Unit-Unit IPAL meliputi: Bak Kontrol / bak Pengendapan awal, Flow Meter Inlet, Tandon Pengendapan / ruang separasi, Tangki anaerob, Tangki aerob, Bak Pengendapan akhir, Pompa Fitration, Tangki Fitration, Flow Meter Outlet dan Tandon Efluen. Berikut Diagram Alur IPAL RSUD Syarifah Ambami Ratu Ebo Bangkalan. Desain IPAL dan Fungsinya. 


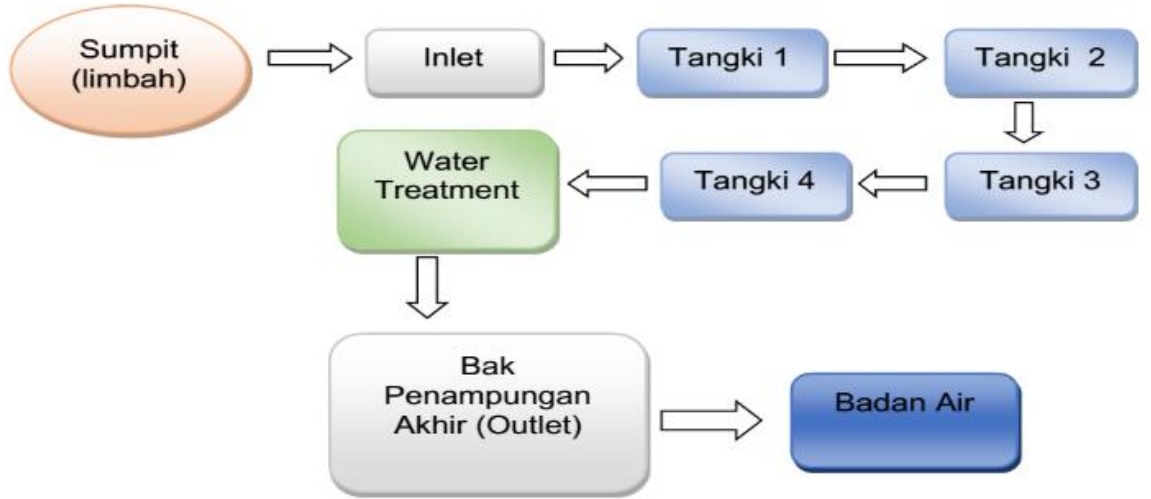

Gambar 1. Proses Pengolahan Limbah Cair Rumah Sakit Syamrabu Bangkalan

- Support atas dan bawah: FRP net

Tahapan pengolahan limbah cair di IPAL RSUD Syarifah Ambami Ratu Ebo Bangkalan.

\section{Ruang Separasi}

Semua limbah cair yang dikeluarkan dari kegiatan rumah sakit masuk kedalam ruangan Separasi untuk mengendapkan partikel lumpur, pasir dan kotoran organik tersuspensi. Selain sebagai ruang pengendapan juga berfungsi sebagai ruang pengontrol aliran yang juga sebagai ruang equalisasi, serta ruang pengurai senyawa organic yang berbentuk padatan, Sludge Digestion (Pengurai Lumpur) dan penampung lumpur.

\section{Ruang Anaerob}

Air limpasan dari ruang pengendap awal selanjutnya dialirkan ke ruang kontraktor anaerob dengan arah aliran dari atas ke bawah dan dari bawah ke atas. Didalam ruang kontraktor tersebut diisi dengan media yang terdiri dari:

- Media Anaerob: HDPE (Height Density Polyethilene)

- Aupport atas dan bawah: FRP net

- Weir/buffle: FRP

Jumlah ruangan kontraktor Anaerob terdiri dari dua buah ruangan.

Penguraian zat-zat organik yang ada dalam limbah cair dilakukan oleh bakteri Anaerobic atau facultatif Aerobic.

Mikroorganisma inilah yang akan menguraikan zat organic yang belum sempat terurai pada bak pengendap.

\section{Ruang Aerob}

Air limpasan dari ruang kontraktor anaerob kemudian dialirkan ke ruang aerob. Didalam ruang kontraktor tersebut diisi dengan media yang terdiri dari:

- Media Aerob: PE (Polyethilene)
- Weir/Buffle: FRP

Didalam ruang kontraktor Aerob terjadi aerasi dengan dihembuskannya udara melalui diffuser sehingga mikroorganisma yang ada akan menguraikan zat organic dan menempel pada permukaan media. Dengan demikian limbah cair akan kontak dengan mikroorganisma yang tersuspensi dalam limbah cair maupun yang menempel pada permukaan media, sehingga meningkatkan efisiensi penguraian zat organic, detergen serta mempercepat proses nitrifikasi.

\section{Ruang Dezparticalization}

Ruang Dezparticalization merupakan satu bagian ruangan terpisah yang berada dalam kontraktor aerasi. Dalam ruangan ini senyawa komplek organik akan terurai oleh aktifitas mikroorganisme aerob.Mikroorganisme tersebut dalam aktifitasnya memerlukan oksigen atau udara untuk memecah senyawa organic yang komplek menjadi $\mathrm{CO}_{2}$ (karbondioksida) dan air serta ammonium, selanjutnya ammonium akan diubah menjadi nitrat dan $\mathrm{H}_{2} \mathrm{~S}$ akan dioksidasi menjadi sulfat. Sehingga effisiensi penghilangan amonia menjadi lebih besar.

\section{Ruang Sedimentasi}

Setelah melalui ruang aerasi kemudian menuju ruang sedimentasi yang memungkinkan terjadinya pemisahan antara air dan lumpur. Diruangan sedimentasi ini lumpur aktif yang mengandung massa mikroorganisma diendapkan yang kemudian akan dikembalikan ke ruang 
anaerob dengan pompa sirkulasi lumpur.

Air limpasan (over flow) dari ruang sedimentasi masuk kedalam ruangan ini sudah merupakan air hasil olahan siap buang kesaluran kota (drainase) setelah terkontak dengan chlorine yang bertujuan untuk membunuh kuman pathogen yang merugikan, proses klorin ini dengan perlakuan penambahan Klorin atau Kaporit sebagai disinfektan. Dengan kombinasi Biotank Filter Anaerob-Aerob sehingga dapat menurunkan zat organic (BOD dan COD), ammonia, detergen, padatan tersuspensi (TSS), phospat dan lainnya

Tabel 1. Kualitas Parameter Limbah Cair RSUD Syarifah Ambami Rato Ebu Bangkalan

\begin{tabular}{|c|c|c|c|c|c|c|}
\hline PARAMETER & SATUAN & $\begin{array}{l}\text { BAKU } \\
\text { MUTU }\end{array}$ & MDL & HASIL & METODA & KET \\
\hline \multicolumn{7}{|l|}{ 1. FISIKA } \\
\hline SUHU*) & ${ }^{\circ} \mathrm{C}$ & 30 & - & 27,5 & $\begin{array}{c}\text { SNI 06-6989 } \\
23-2005\end{array}$ & \\
\hline TSS & $\mathrm{mg} / \mathrm{L}$ & 30 & - & 12,8 & $\begin{array}{c}\text { APHA2540- } \\
\text { D,Ed23.2017 }\end{array}$ & \\
\hline \multicolumn{7}{|l|}{ 2. KIMIA : } \\
\hline $\mathrm{PH}$ & & $6-9$ & - & 7,69 & $\begin{array}{c}\text { SNI06- } \\
698911- \\
2004\end{array}$ & \\
\hline BOD5 & & 30 & 1,00 & 17,9 & $\begin{array}{l}\text { SNI698972- } \\
2009\end{array}$ & \\
\hline COD & & 80 & 3,84 & 40,7 & $\begin{array}{l}\text { APHA5220C. } \\
\text { Ed23.2017 }\end{array}$ & \\
\hline $\mathrm{NH} 3-\mathrm{N}$ & & 0,1 & 0,0206 & 1,05 & $\begin{array}{c}\text { SNI06 } \\
6989.30 \\
2005 \\
\end{array}$ & \\
\hline PO4 (Ortho) & & 2 & 0,0109 & 0,960 & $\begin{array}{c}\text { APHA } \\
\text { 4500P- } \\
\text { E,Ed23.2017 }\end{array}$ & melebihi \\
\hline \multicolumn{7}{|c|}{ 3.BAKTERIOLOGI } \\
\hline Kuman Gol. Coli & $/ 100 \mathrm{ml}$ & 10.000 & - & 35.000 & $\begin{array}{l}\text { AOAC.Ed.20- } \\
2016\end{array}$ & Melebihi \\
\hline
\end{tabular}

\section{KESIMPULAN}

Sistem Pengolahan Limbah Cair di Rumah Sakit Syamrabu Bangkalan menggunakan proses pengolahan secara fisik, kimia dan biologi.

Kualitas limbah cair Rumah Sakit Syamrabu Bangkalan di lihat dari parameter utama yakni $\mathrm{Ph}, \mathrm{BOD}, \mathrm{COD}$ dan TSS sesuai baku mutu limbah cair bagi kegiatan rumah sakit berdasar Pergub Jatim No. 72 tahun 2013, sedangkan untuk parameter NH3-N dan E Coli hasilnya diatas baku mutu limbah cair.

\section{SARAN}

Sebaiknya pihak manajemen rumah sakit mengganti mesin blower yang mati diganti dengan mesin yang baru sehingga bisa berfungsi secara maksimal untuk mengatasi menurunkan kadar $\mathrm{NH} 3$ yang melebihi baku mutu Sedangkan untuk E Coli yang melebihi baku mutu, agar proses penambahan klorin sesuai dosis yang diperlukan, sehingga bisa lebih optimal dalam membunuh bakteri.

\section{DAFTAR PUSTAKA}

Arifin M, 2008, Pengaruh Limbah Rumah Sakit Terhadap Kesehatan. FKUI, Jakarta.

Apruss 2005, Pengelolaan Aman Limbah Layanan Kesehatan, Jakarta: 
Penerbit Buku Kedokteran, EGC.

Bonas A, 2013, Pengelolaan sampah/ limbah rumah sakit dan permasalahannya.

Departemen Kesehatan RI, 2006, Pedoman Penatalaksanaan Pengelolaan Limbah Padat dan Limbah Cair Rumah Sakit. Jakarta

Chrstina dan Sugito. 2016. Redesain Instalasi Pengolahan Limbah cair IPAL Terpusat Menggunakan Sistem Anaerobik Aerobik Biofilter Di RSUD Dr. Soetomo Surbaya. Jurnal Teknik WAKTU Volume 14 nomor 01-Januari 2016-ISSN :1412-1867

Djabu,U, Kusmantoro, H, dkk, 1990, Pedoman Bidang Studi Pembuangan Tinja dan Limbah cair.

Djohan, A, 2013, Pengeioiaan Limbah Rumah Sakit. Jakarta

Erika, D1, Henny Medyawanti, 2011, Evaluasi Sistem Manajemen Pengeioiaan Limbah Rumah Sakit, Jurnai PESAT (Psikoiogi, ekonomi, sastra, arsitektur dan sipii), Volume
4, Oktober 2011

Haryani, Nurfi T, Sarto. 2018, Evaluasi penggunaan Biofilter anaerob- aerob untuk meningkatkan kualitas air iimbah rumah sakit.

Keputusan Menteri Kesehatan RI nomor 1204 / Menkes / SK / X / 2004, tentang Persyaratan Kesehatan Lingkungan Rumah Sakit.

Kulkarni, Sunil J, dkk.2015, Research on Advanced Biological Effluent Treatment: A. Review. International Journal Of Research and review EISSN:2349-9788;P- ISSN:2454-2237.

Kurnia. 2009. Parameter Pengolahan Limbah cair Industri (terhubung berkala) http://maiarimagazine.com(16)

Prehatin Trirahayuningrum, Nita Nurinda Khalista. 2014, Gambaran Pengelolaan Limbah Cair di Rumah Sakit X Kabupaten Jember, Jurnal IKESMA Volume 10 nomor 2September 2014. 